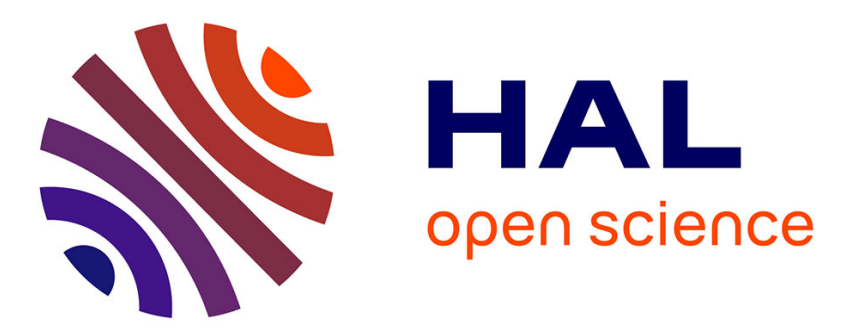

\title{
Estrogen levels act as a rheostat on p53 levels and modulate p53-dependent responses in breast cancer cell lines
}

Lynnette Fernández-Cuesta, Suresh Anaganti, Pierre Hainaut, Magali Olivier

\section{- To cite this version:}

Lynnette Fernández-Cuesta, Suresh Anaganti, Pierre Hainaut, Magali Olivier. Estrogen levels act as a rheostat on p53 levels and modulate p53-dependent responses in breast cancer cell lines. Breast Cancer Research and Treatment, 2010, 125 (1), pp.35-42. 10.1007/s10549-010-0819-x . hal-00554995

\section{HAL Id: hal-00554995 \\ https://hal.science/hal-00554995}

Submitted on 12 Jan 2011

HAL is a multi-disciplinary open access archive for the deposit and dissemination of scientific research documents, whether they are published or not. The documents may come from teaching and research institutions in France or abroad, or from public or private research centers.
L'archive ouverte pluridisciplinaire HAL, est destinée au dépôt et à la diffusion de documents scientifiques de niveau recherche, publiés ou non, émanant des établissements d'enseignement et de recherche français ou étrangers, des laboratoires publics ou privés. 
Estrogens levels act as a rheostat on p53 levels and modulate p53-dependent responses in breast cancer cell lines

Lynnette Fernández-Cuesta, Suresh Anaganti, Pierre Hainaut, Magali Olivier

Molecular Carcinogenesis Group, International Agency for Research on Cancer, Lyon, France

\section{Correspondence to:}

Dr Magali Olivier, Molecular Carcinogenesis Group, International Agency for Research on Cancer, Lyon, France; molivier@iarc.fr.

\section{Running title:}

Effects of estrogens on p53 levels and activity.

\section{Key words:}

p53, estrogen receptor, breast, estradiol, doxorubicin, apoptosis 


\section{Abstract}

A large proportion of breast cancers express the estrogen receptor alpha (ER $\alpha)$ and are dependent on estrogens for their proliferation and survival. The tumor suppressor TP53 encodes the p53 protein, an important mediator of the anti-proliferative and apoptotic effects of several treatments used for breast cancer. A significant proportions of breast tumors (20-30\%) carry mutations in TP53 gene and these mutations are associated with poor survival and poor response to several types of chemotherapeutic treatments. While there is mounting evidence for functional interactions between p53 and ER $\alpha$ pathways in breast and other tissues, the impact of these interactions on response to chemotherapy and anti-hormone treatments remain largely unknown. Here, using estrogen-dependent breast cancer cell lines with different p53 status, we show that estrogens, through ER $\alpha$, influence p53 protein levels and activities. Estrogens deprivation reduced, while estradiol increased p53 levels, in a time and dose-dependent manner. Both wild-type and endogenously expressed mutant p53 proteins were affected. This reduction in p53 protein levels resulted in reduced p53-dependent responses induced by DNA-damage in p53 wild-type cells, lowering the capacity of doxorubicine to induce apoptosis. The p53 response appeared to be quantitatively but not qualitatively affected. These results suggest that $E R \alpha$ activity is required for a strong p53 response in estrogen-dependent breast cancer cells. These results are in line with previous observations that we made in a clinical series, where a larger effect of TP53 mutation status was found for patient survival in cases with progesterone receptor positive status, a marker of a functional ER $\alpha$ pathway. It would thus be important to further characterize the influence of ER $\alpha$ pathway on the predictive value of TP53 mutation status in specifically designed clinical trials, as it may open perspectives for improving breast cancer treatment. 


\section{Introduction}

The tumour suppressor gene TP53 encodes the p53 protein, a stress induced transcription factor that exerts anti-proliferative activities through the regulation of genes involved in the control of apoptosis, cell cycle checkpoints and senescence [1]. Because TP53 constitutes a major barrier to cancer development it is frequently mutated in various types of human cancers [2]. In breast cancer, TP53 mutations are associated with poor prognosis and several studies have reported an association with poor response to different types of chemotherapy drugs [3].

The estrogen receptor $E R \alpha$ is a member of the nuclear receptor family of transcription factors that mediates the effect of estrogens via genomic (i.e. regulation of gene expression requiring specific co-regulator proteins) and non-genomic activities that results in the control of cell growth, survival, differentiation, apoptosis, and angiogenesis [4]. Non-genomic activities include rapid cellular signaling by direct interaction of cytoplasmic ER $\alpha$ with a variety of trans-membrane growth factor receptors such as EGFR or HER2 $[5 ; 6]$.

Several lines of evidence suggest that p53 and ER $\alpha$ can influence each other activities through different mechanisms. Complexes between p53 and ER $\alpha$ proteins have been described that can modulate their stability [7;8]. ER $\alpha$ has been shown to control p53 mRNA expression $[9 ; 10]$ and vice-versa $[11 ; 12]$. p53 can also down-regulate ER $\alpha$ responsive genes by interfering with the binding of $E R \alpha$ to its response element (RE) [1315], and reciprocally, $E R \alpha$ can repress $p 53$ function [16-18]. Positive regulation of $E R \alpha$ and p53 may also cooperate in the induction of some genes through p53 and ER $\alpha$ REhalf-sites located in promoter regions [19]. Despite these studies, several inconsistent results were reported and the nature, context (ligand-dependent or independent) and biological impacts of these interactions remain to be elucidated.

It is well established that p53 participates in the anti-proliferative and apoptotic activities of several anti-cancer drugs that damage DNA, that may account for its prognostic and predictive values in breast cancer [20]. In a large series of 1794 patients with breast cancers we previously observed that the prognostic value of TP53 mutation status was stronger in progesterone receptor (PR) positive cases [21]. Since PR expression is a marker for a functional estrogen receptor pathway, these results suggested that a functional ER $\alpha$ pathway may be required for an efficient p53 response in estrogen-dependent breast cancer. To test this hypothesis in cellular models, here we used estrogen-dependent breast cancer cell lines with different TP53 status to investigate how estrogens may influence p53 dependent biological responses. 


\section{Materials and methods}

\section{Cell lines and treatments}

MN1 ( $p 53 W T$ ) and MDD2 ( $p 53 M U T$ ) cells are isogenic cell-lines derived from MCF-7 cells that have been established in 1992 (kindly provided by M. Oren, Weizmann Institute). MDD2 cells are stably transfected with a p-CMV-DD plasmid expressing a p53 mini protein that contains the first 14 and last 89 amino acids of the mouse p53 protein [22]. This mini p53 protein has strong dominant negative activity due to its heterooligomerisation with the endogenous $\mathrm{p} 53$ protein. This results in the over expression of an inactive $\mathrm{p} 53$ protein in MDD2 cells. MN1 cells were similarly generated by transfection of the control insert-free plasmid followed by G418 selection. MN1 and MCF-7 cells have a similar 553 response when treated with the DNA damaging agent doxorubicin or with estradiol (not shown). These cells were maintained in DMEM (Invitrogen) containing 10\%FBS, 2\%L-glutamine-penicillin-streptomycin solution stabilised (Sigma) and 0,4 mg/ml geneticin (Invitrogen). ZR-75-1 (p53WT) and T-47D (p53MUT, p.L194F) cells were provided by Dr Theillet and BT-474 (p53MUT, p.E285K) by Dr Puisieux. These cells were maintained in RPMI 1640 (Invitrogen). All cells were cultured at $37^{\circ} \mathrm{C}$ at $5 \% \mathrm{CO} 2$. For estrogen-free (EF) conditions, cells were cultured in phenol red-free medium (DMEM/F12 -Gibco- and RPMI 1640 -Invitrogen-), supplemented with 10\% charcoalstripped dextran-treated serum (HyClone), and other components as indicated above. $17 \beta$-estradiol (E2) and doxorubicin (DOX) were purchased from Sigma.

\section{Cell cycle and apoptosis analyses by Flow Cytometry}

DNA synthesis was assessed by BrdU (BD-Pharmingen) incorporation and DNA was stained with PI (Sigma) following standard procedures. Cells were fixed with $70 \%$ ethanol, DNA denatured with $\mathrm{HCl}$ and BrdU revealed with a monoclonal anti-BrdU antibody (BD-Pharmingen). Apoptosis was measured with FITC-Annexin V (BDBiosciences) following manufacturer's instructions. Data acquisition and analysis were done on a FACS BDLSRII machine using Cell-Quest software. Each experiment was repeated at least twice.

\section{Gene silencing}

siRNA directed against ER $\alpha$ (ID:42835), TP53 (ID:106141), and scramble RNA (scr) which do not recognize any human mRNA (ID:4611) were purchased from Ambion. siRNAs were transfected into cells with HiPerfect (Quiagen) according to the manufacturer's protocol. ER $\alpha$ and p53 mRNA and protein levels were monitored by qPCR and Western-blot respectively. 


\section{B-galactosidase assay}

Cells were cultured for $48 \mathrm{~h}$ in EF medium before transfection, by using FuGene6 reagent (Roche), of p53 reporter plasmid, pRGCAFosLacZ, containing the RGC (Ribosomal Gene Cluster) p53 binding site upstream of the $\beta$-galactosidase. $24 \mathrm{~h}$ after transfection, different concentrations of E2 were added for $24 \mathrm{~h}$ and $\beta$-galactosidase activity was measured using $\beta$-Galactosidase Enzyme Assay (Promega) according to the manufacturer's instructions.

\section{Protein analyses}

Protein extracts were prepared by lyzing cells with RIPA-like buffer $(250 \mathrm{mM} \mathrm{NaCl}, 50 \mathrm{mM}$ Tris- $\mathrm{HCl} \mathrm{pH} 7.4,0.1 \%$ SDS, $2 \mathrm{mM}$ DTT and $0.5 \%$ Igepal) containing proteases inhibitors (Complete-Mini, Roche) and phosphatase inhibitors (HALT ${ }^{\mathrm{TM}}$ PhosphataseInhibitor Cocktail, PIERCE). Equal amounts of total proteins were separated on a $10 \%$ SDS-PAGE gel and transferred to a PVDF-membrane (Roche). Antibodies and dilutions used are listed in Supplementary Table 1. Protein signals were revealed using Amersham ${ }^{T M} \mathrm{ECL}$ Western-blotting Detection Reagents and Amersham ${ }^{T M}$ Hyperfilm ECL. Each experiment was repeated at least twice.

\section{q-PCR a nalysis}

Total RNA was isolated using the Nucleospin-RNAII kit (Macherey-Nagel) and cDNA was produced by using the SuperScriptII Reverse-Transcriptase (Invitrogen) and random primers (Promega) following manufacturer's instructions. Real-time PCR was carried out in a Stratagene $\mathrm{M} \times 3000$ using SyBrGreen mixture (Quiagen) and primers. PCR conditions were as follows: $95^{\circ} \mathrm{C}, 15 \mathrm{~min}(1 \mathrm{cycle}) ; 94^{\circ} \mathrm{C}, 15 \mathrm{~s}$ and $60^{\circ} \mathrm{C}, 30 \mathrm{~s}$ (50cycles); $72^{\circ} \mathrm{C}, 30 \mathrm{~s}$ (1cycle). Primers are listed in Supplementary Table 2. PCR for each gene fragment was performed in triplicate, and each primer set was repeated 2 or 3 times. The relative mRNA levels were calculated using the $\Delta \Delta$ Ct method with the endogenous $28 \mathrm{~S}$ mRNA as normalizer.

\section{Statistical and densitometry analyses}

Statistical analyses were performed using Student's t-test, assuming equal variance, and p-value was calculated based on two-tailed test. A p-value of $<0.05$ was considered statistically significant (indicated as $*$ in figures, and $* *$ when $\mathrm{p}$-value $<0.01$ ). Densitometry analyses of Western-blots were performed with the public domain NIH Image program available at: http://rsb.info.nih.gov/nih-image. 
Estrogens impact on wild-type and mutant 553 protein levels

Five estrogen dependent breast cancer cell lines with different p53 status were used in this study, including an isogenic model (MN1 and MDD2) derived from MCF-7 cells (see Methods). When maintained for at least $48 \mathrm{~h}$ in an estrogen-free (EF) medium, all cell lines showed a reduced proliferation (Supl. Figure 1A) and accumulation in G1 phase (as shown for MN1 and MDD2 cells in Supl. Figure 1B). The mRNA expression of the ER $\alpha$ target gene, TFF1, was also significantly reduced, indicating a reduction in ER $\alpha$ genomic activity (Supl. Figure 1C). In these conditions, p53 protein expression was reduced in all cells expressing an endogenous protein (Figure 1A), from 1.5-fold change in T-47D to 2.5-fold change in BT-474 (Supl. Figure 1D). In contrast, TP53 mRNA expression was not reduced and even slightly up-regulated (Figure 1B). Protein levels were further decreased when cultured for a longer time in EF conditions reaching a plateau at 8 days, as observed in MN1 (Supl. Figure 2). The decrease in p53 protein levels under estrogen deprivation was confirmed by immuno-fluorescence assays in MN1 cells (Figure 1C) and showed that both cytoplasmic and nuclear levels of p53 were decreased to undetectable levels in EF conditions.

Since basal p53 protein levels are known to be controlled through degradation by the proteasome [23], we tested whether inhibiting the proteasome could restore p53 levels in estrogen deprived conditions. The proteasome inhibitor lactacystin was added for $8 \mathrm{~h}$ to MN1 and ZR-75-1 cells cultured in EF medium for 40h. As shown in Figure 1D, lactacystin treatment caused a strong increase in p53 protein levels. Thus, blocking the proteasome increased wild-type p53 protein levels in E2-deprived cells as in normal conditions.

To verify that this effect on p53 levels was due to the removal of estrogens and not other steroids, $15 \mathrm{nM} 17 \beta$-estradiol (E2) was added for $48 \mathrm{~h}$ on cells cultured in EF medium. These conditions activated ERa genomic activity as shown by an increase in TFF1 expression (Supl. Figure 1C). p53 protein levels were increased by E2 (Figure 1A), from 1.4-fold change in T-47D to 2.2-fold change in MN1 cells (Supl. Figure 1D). Thus, although p53 mutant proteins are expressed at higher levels than wild-type proteins in basal conditions (CM), E2 manipulation affected both wild-type and mutant proteins levels.

These effects on protein levels were correlated with p53 transcriptional activity on a p53 response-element (RGC, see Methods) in MN1 cells using a $\beta$-galactosidase reporter assay (Figure 1E). $\beta$-galactosidase activity was reduced in EF conditions 
compared to complete medium (CM), and addition of E2 at increasing doses resulted in a dose-dependent increase in reporter activity in MN1 but not in the MDD2 cells that express an inactivated p53 protein (Figure 1E). Thus, variations observed in p 53 wildtype protein levels upon E2 manipulation correlated with p53 protein activity, showing that estrogens can influence $\mathrm{p} 53$ expression and activity.

Overall, these data show that estradiol levels affect both wild-type and mutant p53 protein expression by a mechanism acting at the protein level. E2 deprivation decreased, while E2 treatment increased, p53 protein levels that correlated with p53 transactivation activity.

\section{ERa silencing reduces p53 protein levels}

$\mathrm{ERa}$ is the main target of estrogens that bind to and activate this receptor. Estrogens are also known to influence ERa degradation by the proteasome. Estrogens withdrawal has been shown to cause the accumulation of an inactive ERa protein while the addition of estradiol reinitiate proteasomal degradation and reduce ERa protein levels [24;25]. As shown in Figure 1A, ERa protein levels were increased in EF conditions and decreased upon E2 supplementation in all cell lines, as expected. The genomic activity of ERa varied in opposite way (decreased by EF conditions and increased by E2 addition) as assessed by the mRNA expression of the ERa target gene TFF1 that was decreased in EF conditions and increased by E2 addition (Supl. Figure 1C). Thus, the decrease in p53 protein levels observed in EF conditions correlated with an increase in ERa protein that has low genomic activities.

To assess the role of ERa in the reduction of $\mathrm{p} 53$ protein levels, ERa was silenced in MN1 and ZR-75-1 cells maintained in CM or EF conditions. Figure 2A shows that ERa SiRNA efficiently reduced ERa protein levels and caused a decrease in p53 levels both in the presence (Figure 2A, upper panel) or absence of E2 (Figure 2A, lower panel). It is of note that in EF conditions, where p53 levels are already low, the reduction upon ERa silencing is very small (1.4-fold change in MN1 and 1.7-fold change in ZR-75-1) compared to the reduction seen in CM (7.1-fold change in MN1 and 8.2-fold change in ZR-75-1) (Supl. Figure 1D). Interestingly, ERa siRNA in CM slightly increased p53 mRNA levels (Figure $2 B$ ) as observed under E2-deprivation (Figure 1B). Thus, silencing ERa had similar effects than removing estrogens. It is of note that silencing ERa in the p53 mutated cells BT-474 also reduced p53 protein levels (not shown).

These results show that eliminating estrogens, silencing $\mathrm{ERa}$, or both, caused a reduction in basal p53 protein levels, while p53 mRNA levels were slightly increased. This 
suggests that estrogens affect p53 protein levels through a mechanism that involve E2liganded ERa.

\section{Estrogen deprivation compromises p53-dependent responses}

To address the consequences of reduced p53 levels on DNA damage induced p53 responses, E2-deprived cells were treated with doxorubicin (DOX). DOX is a chemical inducer of DNA damage and well-known activator of the p53 pathway. Indeed, in CM, treatment with DOX for $24 \mathrm{~h}$ induced apoptosis (Supl. Figure 3A), p53 protein accumulation (Supl. Figure $3 \boldsymbol{B}$ ) and activation of p53 targets (Supl. Figure $3 \boldsymbol{B}$ and 3C) in p53 wild-type but not mutant cell lines, showing that p53 plays a role in DOXinduced apoptosis in these cells. In MN1 and ZR-75-1 cells grown in EF medium, apoptosis induced by DOX was significantly reduced compared to CM condition (Figure 3A). DOX-induced levels of p53 protein and its targets, p21 and Mdm2, were also lower in $\mathrm{EF}$ conditions compared to $\mathrm{CM}$ in both cell lines, although the difference was stronger in MN1 cells than in ZR-75-1 (Figure 3B). This reduction in p53 protein level correlated with a significant reduction in the induction of some p53 target genes such as 14.3.3, PUMA and GADD45, as assessed by qRT-PCR (Figure 3C). In contrast, the repression of $B C L 2$ and induction of $B A X$ were similar in EF condition and $C M$ in both cell lines (Figure 3D).

These results show that estrogen deprivation alters the intensity of the p53 response and compromises the induction of apoptosis induced by doxorubicin in p53 wild-type cells. 


\section{Discussion}

In this manuscript, we show that estrogens levels act as a rheostat on p53 steady-state levels and impact on p53 dependent responses induced by the DNAdamaging agent DOX. We also provide evidence that this regulation occurs at the protein level and involves the estrogen receptor $\mathrm{ER} \alpha$.

We first show that low levels of estrogens reduced, but high levels increased p53 protein expression and activity. Both wild-type and mutant p53 proteins were affected. These results are in agreement with previous data obtained in MCF-7 and T-47D cell lines [10]. Here, we confirm and extend these observations in other breast cancer cell lines with different p53 status, providing further evidence that estrogen levels affect both wildtype and mutant p53 protein levels in different cellular backgrounds. This effect did not occur at the transcriptional level since p53 mRNA levels were not decreased but even slightly increased in low estrogens conditions in all cell lines. In contrast to previous reports $[17 ; 18]$, estrogens manipulation did not affect p53 sub-cellular distributions in any of the cell-lines analyzed here. The reasons are unclear but may be related to differences in culture conditions.

The main target of estrogens is ERa. In the absence of estrogens, it has been reported that ERa may cross-talks with HER2 and impact on p53 stability via Akt/Mdm2 [26]. However, we showed that ERa silencing had similar effects on p53 expression than removing estrogens. It is thus not likely that ligand-independent activities of ERa are involved. Instead, a decrease in ERa E2-dependent activities or in E2-liganded ERa protein may be responsible for the decrease in p53 protein expression observed in EF conditions. p53 protein levels are known to be tightly controlled in the cell through proteasome-dependent degradation mediated by $\mathrm{mdm} 2$, one of $\mathrm{p} 53$ target gene [27]. Complexes between p53-ERa, ERa-Mdm2 and p53-Mdm2, as well as ternary complexes between ERa, Mdm2 and p53 have been described that may impact on p53 and ERa stability [7;28]. In one study it was suggested that ERa may protect p53 from deactivation by Mdm2 [8]. However, the role of E2 in these interactions remained unclear. Here, we showed that low p53 levels in EF conditions were restored by inhibiting the proteasome. We also observed that inhibition of p53-mdm2 interaction with the small peptide nutlin- 3 also restored p53 protein levels in EF conditions (not shown). This suggests that $p 53$ regulation by the proteasome is active and may be enhanced in the absence of estrogens, due to changes in the composition or stoichiometry of ERa-p53Mdm2 complexes. However, further experiments are needed to investigate this hypothesis. 
We next addressed the consequences of reduced wild-type p53 protein levels on p53 responses in MN1 and ZR-75-1 cells cultured in EF conditions. First, reduced p53 levels in MN1 cells correlated with reduced activity of a p53RE in a reporter assay. Then, using a DOX treatment to induce a p53 response, we showed that the nuclear accumulation of p53 protein and the induction of classical p53 target genes was lowered in $\mathrm{EF}$ medium compared to $\mathrm{CM}$, and this reduction correlated with a reduction in DOXinduced apoptosis. The p53 response seemed to be quantitatively but not qualitatively reduced in EF compared to CM conditions. Because induction of p53 by DNA damaging treatments such as DOX is known to be due to the stabilization of the protein, our results suggest that lower levels of protein at the start of treatment result in lower levels of activated protein. Lower levels of activated protein result in a reduced p53 response (activation of target genes) that may not be sufficient to induce an apoptotic response. These results are in line with previous reports. One study in MCF-7 cells reported a reduction in DNA-damage-induced p53 responses in MCF-7 cells under tamoxifen treatment [31]. Another study provided in vivo evidence of $\mathrm{p} 53$ regulation by estrogens in a mouse model. Indeed, it was shown that pre-treatment of BALB/c-p53 wild-type mice with estradiol (alone or with progesterone) increased p53 responses (apoptosis and p21 expression) induced by irradiation and suppressed mammary tumors [29;30]. Our data thus add experimental evidence that regulation of p53 activity by estrogens can impact on anti-cancer treatments. These data are also in line with our previous observation in a large clinical series where the prognostic value of TP53 mutation status was stronger in PR positive cases than in PR negative cases [21].

The impact of estrogen regulation of p53 mutant proteins remains to be addressed. It has been shown in different cell-based assays as well as in mouse-models that p53 mutant proteins may have pro-oncogenic, gain of function activities $[32 ; 33]$. However, the molecular determinant of this gain of function activity is still a matter of debate and was thus difficult to address in cell lines. Data obtained in the mouse showed that a mutant protein was regulated in a manner similar to wild-type p53 and was only over expressed in tumor cells [34]. Moreover, its stabilization and over expression was necessary for its gain of function activity. Here, levels of endogenous p53 mutant proteins were also modulated by estrogens, although, in T47D cells, a longer treatment in EF conditions was required to obtain a significant reduction in p53 levels (not shown). Estrogen stimulation may thus promote high expression levels of mutant proteins that may favour tumorigenesis and treatment resistance through p53 gain of function activities. It would thus be interesting to investigate the regulation of p53 mutant proteins by $\mathrm{E} 2$ in mouse models. 
In conclusion, this study provide further evidence that estrogens affect p53 levels and function in breast cancer cells and impact on p53-dependent responses to DNA damage. The reduction in p53 activity under low estrogens activity may constitute a general safe guard mechanism to avoid cell death in cells that depend on estrogens for their survival. However, in clinical settings such regulation of p53 activity by estrogens may greatly influence tumor growth and responses to treatments. Specifically designed clinical studies are thus required to further address the clinical relevance of p53 regulation by ERo pathway. For example, it would be important to evaluate in clinical settings the prognostic value of p53 status in patients treated with aromatase inhibitors as, by reducing estrogen levels, they may also reduce p53 anti-proliferative activities.

\section{Acknowledgements}

This work has been supported by a grant from the Association for International Cancer Research. We thank Ke-Seay Smoth for her technical help. 


\section{References}

1 Levine AJ, Momand J, Finlay CA (1991) The p53 tumour suppressor gene. Nature 351:453-456.

2 Hainaut P, Hollstein M (2000) p53 and human cancer: the first ten thousand mutations. Adv Cancer Res 77:81-137.

3 Olivier M, Hainaut P, Borresen-Dale A. Prognostic and predictive value of TP53 mutations in human cancer. In: Ha inaut P, Wiman K, editors. 25 years of p53 research. Springer, 2005: 321-338.

4 Heldring N, Pike A, Andersson S, Matthews J, Cheng G, Hartman J, Tujague M, Strom A, Treuter E, Warner M, Gustafsson JA (2007) Estrogen receptors: how do they signal and what are their targets. Physiol Rev 87:905-931.

5 Cheskis BJ, Greger JG, Nagpal S, Freedman LP (2007) Signaling by estrogens. J Cell Physiol 213:610-617.

6 Santen RJ, Fan P, Zhang Z, Bao Y, Song RX, Yue W (2009) Estrogen signals via an extra-nuclear pathway involving IGF-1R and EGFR in tamoxifen-sensitive and resistant breast cancer cells. Steroids 74:586-594.

7 Duong V, Boulle N, Daujat S, Chauvet J, Bonnet S, Neel H, Cavailles V (2007) Differential regulation of estrogen receptor alpha turnover and transactivation by Mdm2 and stress-inducing agents. Cancer Res 67:5513-5521.

8 Liu G, Schwartz JA, Brooks SC (2000) Estrogen receptor protects p53 from deactivation by human double minute-2. Cancer Res 60:1810-1814.

9 Hurd C, Dinda S, Khattree N, Moudgil VK (1999) Estrogen-dependent and independent activation of the P1 promoter of the p53 gene in transiently transfected breast cancer cells. Oncogene 18:1067-1072.

10 Moudgil VK, Dinda S, Khattree N, Jhanwar S, Alban P, Hurd C (2001) Hormonal regulation of tumor suppressor proteins in breast cancer cells. J Steroid Biochem Mol Biol 76:105-117.

11 Shirley SH, Rundhaug JE, Tian J, Cullinan-Ammann N, Lambertz I, Conti CJ, FuchsYoung R (2009) Transcriptional regulation of estrogen receptor-alpha by $\mathrm{p} 53$ in human breast cancer cells. Cancer Res 69:3405-3414.

12 Angeloni SV, Martin MB, Garcia-Morales P, Castro-Galache MD, Ferragut JA, Saceda $M$ (2004) Regulation of estrogen receptor-alpha expression by the tumor suppressor gene p53 in MCF-7 cells. J Endocrinol 180:497-504.

13 Liu G, Schwartz JA, Brooks SC (1999) p53 down-regulates ER-responsive genes by interfering with the binding of ER to ERE. Biochem Biophys Res Commun 264:359364.

14 Jeffy BD, Hockings JK, Kemp MQ, Morgan SS, Hager JA, Beliakoff J, Whitesell $\mathrm{J}$, Bowden GT, Romagnolo DF (2005) An estrogen receptor-alpha/p300 complex activates the BRCA-1 promoter at an AP- 1 site that binds Jun/Fos transcription factors: repressive effects of p53 on BRCA-1 transcription. Neoplasia 7:873-882. 
15 Jin W, Chen Y, Di GH, Miron P, Hou YF, Gao H, Shao ZM (2008) Estrogen Receptor (ER) \{beta\} or $\mathrm{p} 53$ Attenuates ER \{alpha\}-mediated Transcriptional Activation on the BRCA2 Promoter. J Biol Chem 283:29671-29680.

16 Liu W, Konduri SD, Bansal S, Nayak BK, Rajasekaran SA, Karuppayil SM, Rajasekaran AK, Das GM (2006) Estrogen receptor-alpha binds p53 tumor suppressor protein directly and represses its function. J Biol Chem 281:9837-9840.

17 Lewandowski SA, Thiery J, Jalil A, Leclercq G, Szczylik C, Chouaib S (2005) Opposite effects of estrogen receptors alpha and beta on MCF- 7 sensitivity to the cytotoxic action of TNF and p53 activity. Oncogene 24:4789-4798.

18 Molinari AM, Bontempo P, Schiavone EM, Tortora V, Verdicchio MA, Napolitano M, Nola E, Moncharmont B, Medici N, Nigro V, Armetta I, Abbondanza C, Puca GA (2000) Estradiol induces functional inactivation of p53 by intracellular redistribution. Cancer Res 60:2594-2597.

19 Menendez D, Inga A, Snipe J, Krysiak O, Schonfelder G, Resnick MA (2007) A singlenucleotide polymorphism in a half-binding site creates p53 and estrogen receptor control of vascular endothelial growth factor receptor 1 . Mol Cell Biol 27:2590-2600.

20 Lowe SW (1995) Cancer therapy and p53. Curr Opin Oncol 7:547-553.

21 Olivier M, Langerod A, Carrieri P, Bergh J, Klaar S, Eyfjord J, Theillet C, Rodriguez C, Lidereau R, Bieche I, Varley J, Bignon Y, Uhrhammer N, Winqvist R, JukkolaVuorinen A, Niederacher D, Kato S, Ishioka C, Hainaut P, Borresen-Dale AL (2006) The clinical value of somatic TP53 gene mutations in 1,794 patients with breast cancer. Clin Cancer Res 12:1157-1167.

22 Shaulian E, Zauberman A, Ginsberg D, Oren M (1992) Identification of a minimal transforming domain of p53: negative dominance through abrogation of sequencespecific DNA binding. Mol Cell Biol 12:5581-5592.

23 Salvat C, Aquaviva C, Jariel-Encontre I, Ferrara P, Pariat M, Steff AM, Carillo S, Piechaczyk M (1999) Are there multiple proteolytic pathways contributing to c-Fos, cJun and p53 protein degradation in vivo? Mol Biol Rep 26:45-51.

24 Nawaz Z, Lonard DM, Dennis AP, Smith CL, O'Malley BW (1999) Proteasomedependent degradation of the human estrogen receptor. Proc Natl Acad Sci U S A 96:1858-1862.

25 Wijayaratne AL, McDonnell DP (2001) The human estrogen receptor-alpha is a ubiquitinated protein whose stability is affected differentially by agonists, antagonists, and selective estrogen receptor modulators. J Biol Chem 276:3568435692.

26 Zhou BP, Liao Y, Xia W, Zou Y, Spohn B, Hung MC (2001) HER-2/neu induces p53 ubiquitination via Akt-mediated MDM2 phosphorylation. Nat Cell Biol 3:973-982.

27 Kubbutat MH, Jones SN, Vousden KH (1997) Regulation of p53 stability by Mdm2. Nature 387:299-303.

28 Schiff R, Massarweh S, Shou J, Osborne CK (2003) Breast cancer endocrine resistance: how growth factor signaling and estrogen receptor coregulators modulate response. Clin Cancer Res 9:447S-454S. 
29 Becker KA, Lu S, Dickinson ES, Dunphy KA, Mathews L, Schneider SS, Jerry DJ (2005) Estrogen and progesterone regulate radiation-induced p53 activity in mammary epithelium through TGF-beta-dependent pathways. Oncogene 24:63456353.

30 Dunphy KA, Blackburn AC, Yan H, O'Connell LR, Jerry DJ (2008) Estrogen and progesterone induce persistent increases in p53-dependent apoptosis and suppress mammary tumors in BALB/c-Trp53+/- mice. Breast Cancer Res 10: R43.

31 Guillot C, Falette N, Courtois S, Voeltzel T, Garcia E, Ozturk M, Puisieux A (1996) Alteration of p53 damage response by tamoxifen treatment. Clin Cancer Res 2:1439-1444.

32 Adhikari AS, Iwakuma T (2009) Mutant p53 gain of oncogenic function: in vivo evidence, mechanism of action and its clinical implications. Fukuoka Igaku Zasshi 100: 217-228.

33 Brosh R, Rotter V (2009) When mutants gain new powers: news from the mutant p53 field. Nat Rev Cancer 9:701-713.

34 Terzian T, Suh YA, Iwakuma T, Post SM, Neumann M, Lang GA, Van Pelt CS, Lozano $\mathrm{G}$ (2008) The inherent instability of mutant p53 is alleviated by Mdm2 or p16INK4a loss. Genes Dev 22:1337-1344. 


\section{Figure Legends}

\section{Figure 1. Effect of estrogens on p53 levels and activity.}

(A) Protein levels measured by Western-blot in cells grown in complete medium (CM), or maintained in estrogen-free medium (EF) for $96 \mathrm{~h}$, or maintained in estrogen-free medium for $48 \mathrm{~h}$ before adding $15 \mathrm{nM}$ estradiol (E2) for another $48 \mathrm{~h}$. Actin was used as loading control. (B) TP53 mRNA levels measured by GPCR in cells maintained in EF medium for $48 \mathrm{~h}$ compared to levels in cells grown in CM. (C) Immunostaining of p53 protein in CM or EF medium for $48 \mathrm{~h}$. TOPRO nuclei staining was used as control. (D) p53 protein levels measured by Western-blot in cells grown for $40 \mathrm{~h}$ in EF followed by $8 \mathrm{~h}$ in EF supplemented with $10 \mu \mathrm{M}$ lactacystine (Lact). (E) p53 transactivation activity measured by $\beta$-galactosidase activity on the p53-RGC response element of p53. MN1 and MDD2 cells, transiently transfected with p53-RGC were maintained in EF medium for 48 h before adding increasing amounts of E2. The percentage of activity values relative to the one in MN1 cells growing in CM is indicated. Stars indicate statistical significance.

\section{Figure 2. Silencing ERa decreases p53 protein levels independently of E2.}

(A) Protein levels measured by Western-blot. ZR-75-1 and MN1 cells were cultured for $48 \mathrm{~h}$ in either CM or EF in the presence of either siRNA against ERa (siERa) or a scramble RNA (sc1). (B) TP53 and ESR1 mRNA levels measured by qPCR. mRNA levels were detected after $48 \mathrm{~h}$ in $\mathrm{CM}$ in presence of si ERa and compared to cells transfected with a scramble RNA.

\section{Figure 3. Doxorubicin-induced p53 responses are reduced in the absence of estrogens.}

MN1 and ZR-75-1 cells were maintained for 48h in either CM or EF and treated with $0.9 \mu \mathrm{M}$ doxorubicin (DOX) for 24h. (A) Apoptosis detected by AnnexinV staining. The relative fraction of cells undergoing apoptosis under DOX treatment compared to untreated cells in $\mathrm{CM}$ or EF is indicated. (B) Protein expression of p53 and its targets assessed by Western-blot in DOX treated cells. (C) mRNA expression of selected p53 target genes determined by qPCR. Relative expression in DOX treated cells compared to untreated cells in CM or EF is indicated. 
A

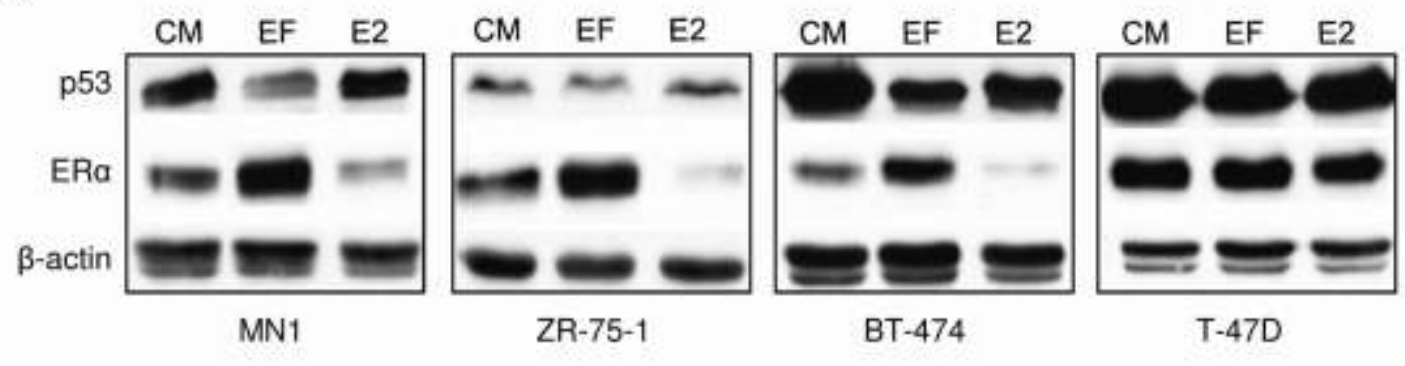

B

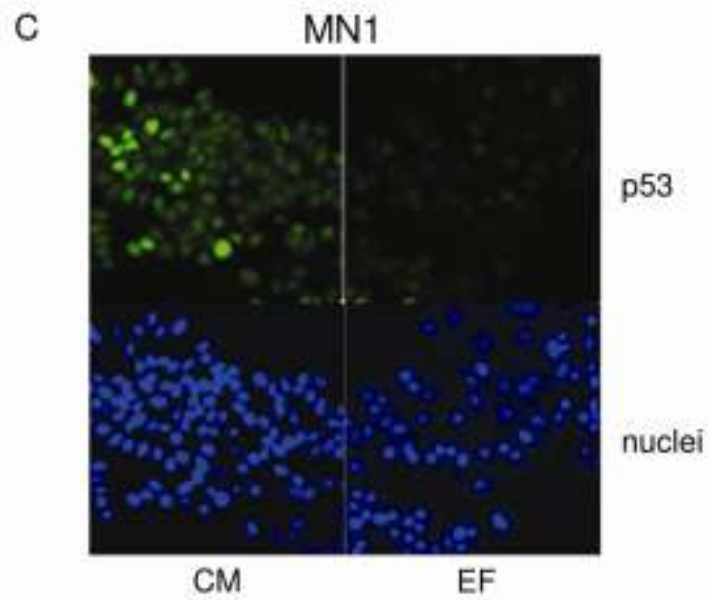

D

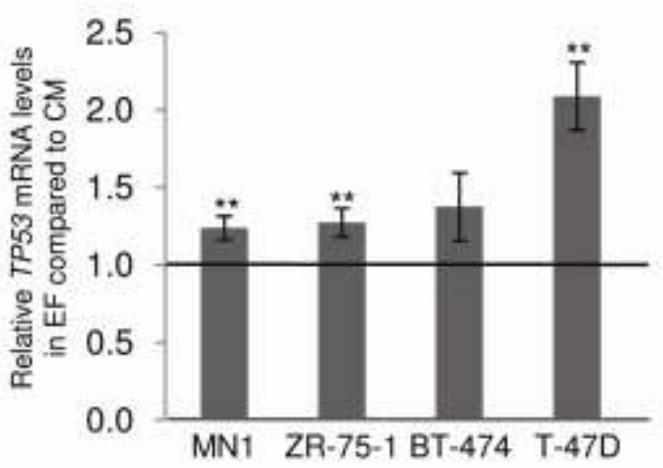

E
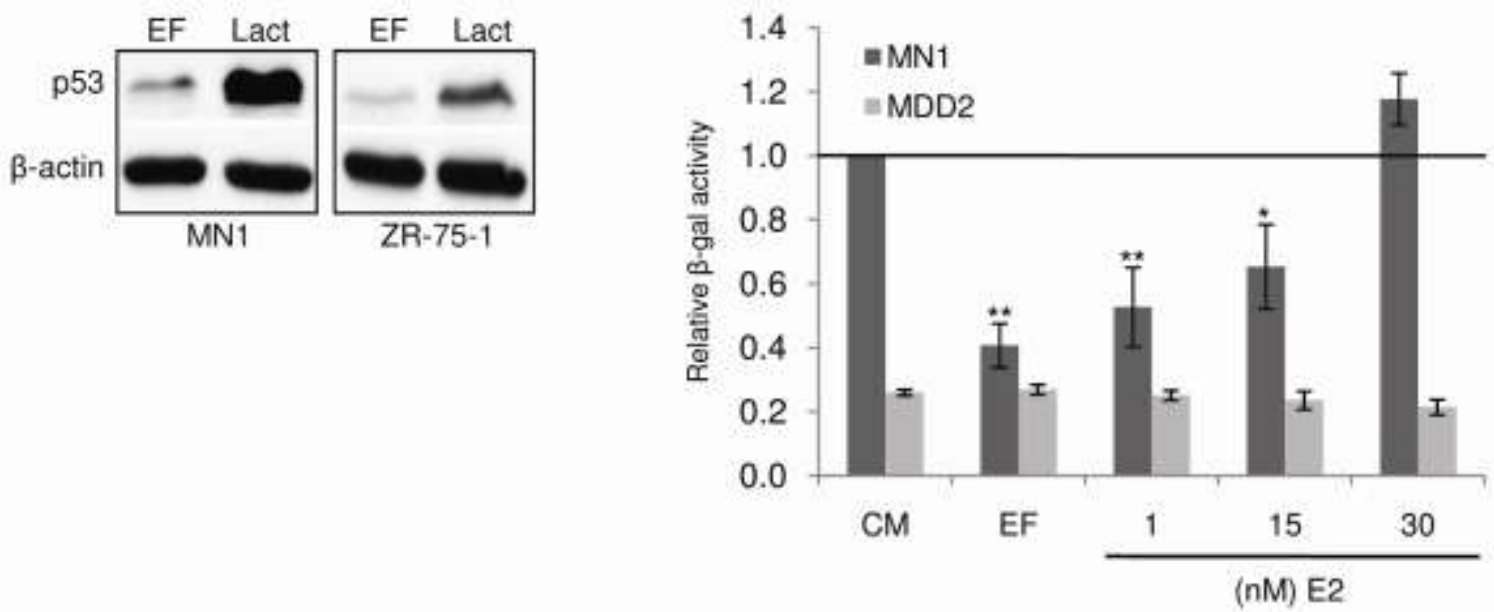
A

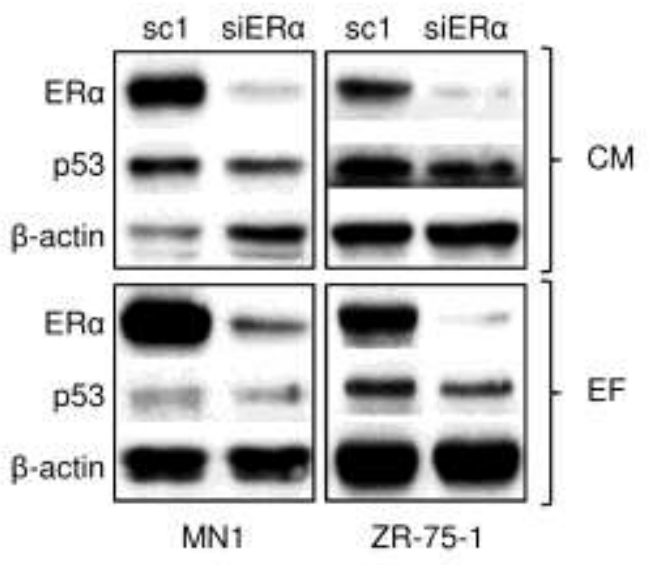

B

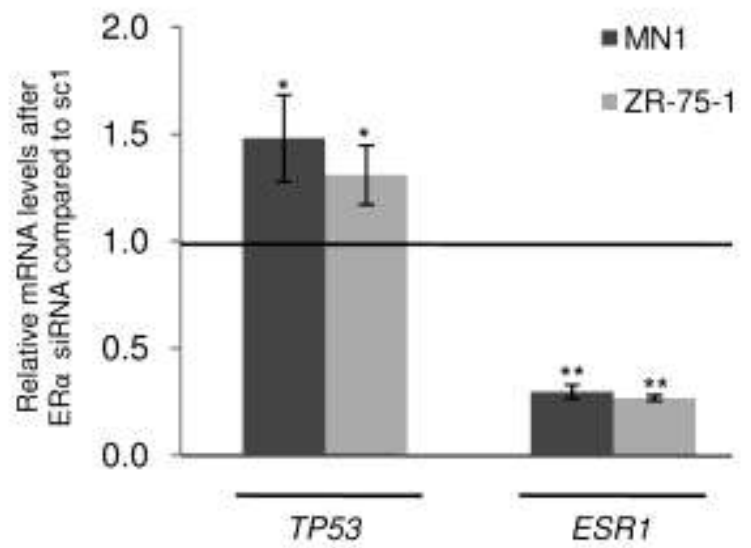


A

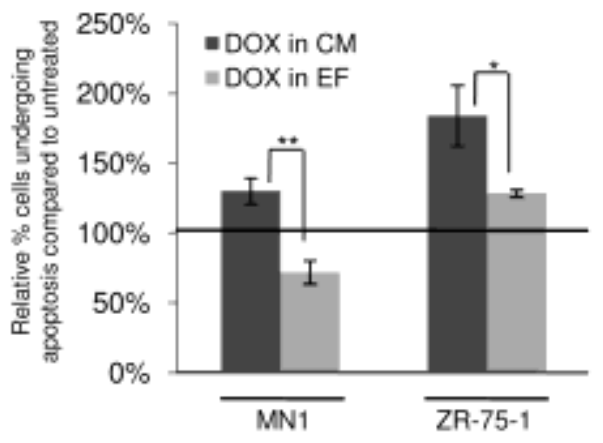

C

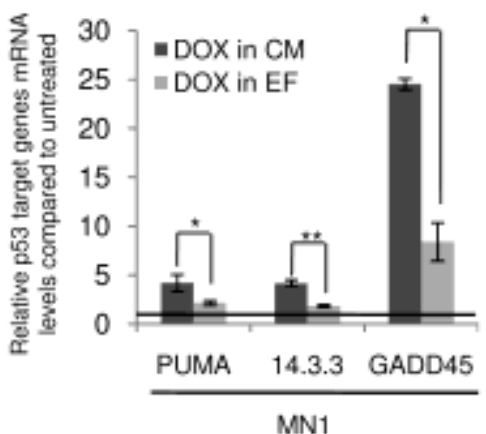

D

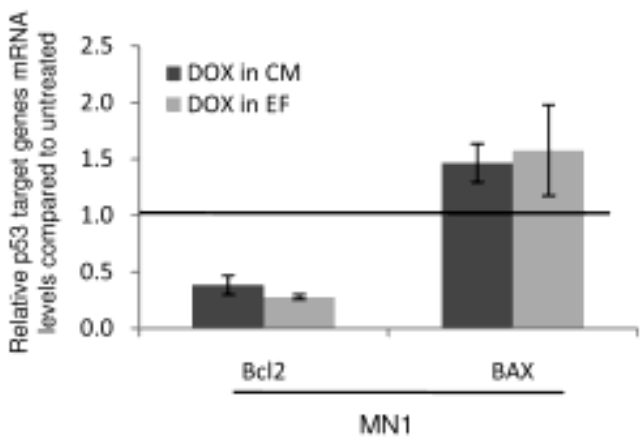

B
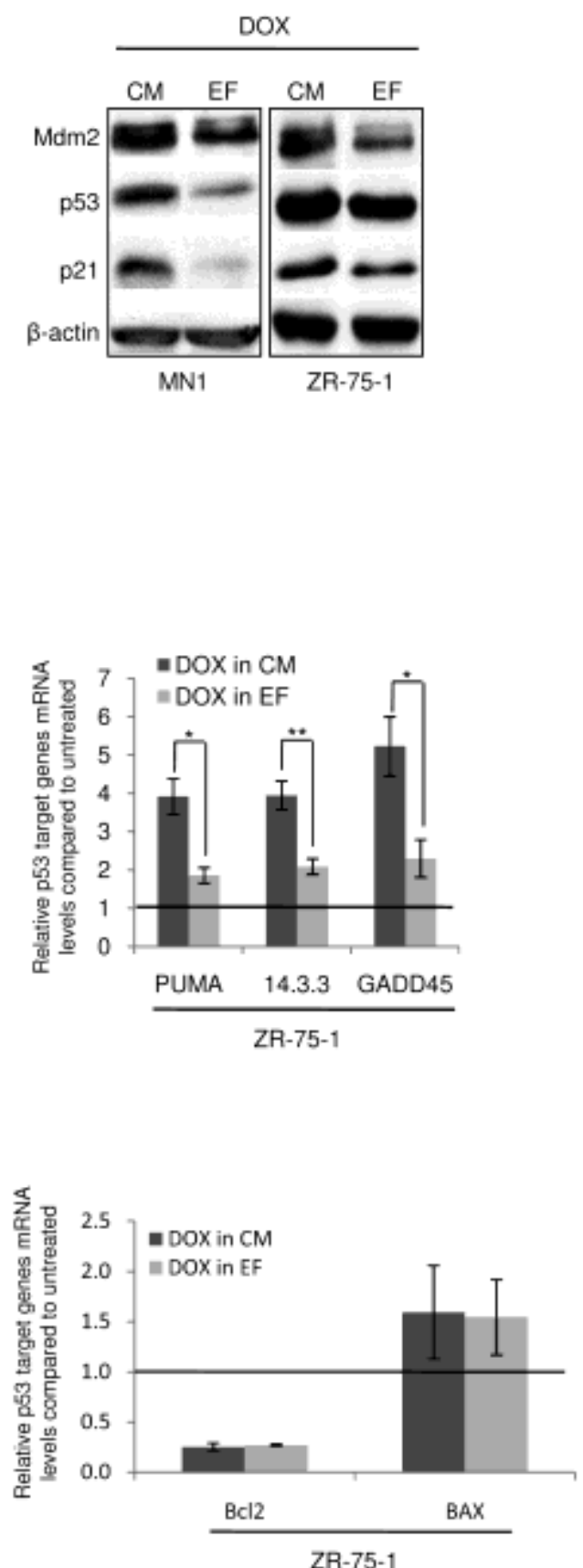